\title{
Abundance, size distribution and bacterial colonization of exopolymer particles in Antarctic sea ice (Bellingshausen Sea)
}

\author{
Klaus Meiners ${ }^{1,2, *}$, Robin Brinkmeyer ${ }^{3}$, Mats A. Granskog ${ }^{4,5}$, Antti Lindfors ${ }^{4}$ \\ ${ }^{1}$ Institute for Polar Ecology, University of Kiel, Wischhofstr. 1-3, Bld. 12, 24148 Kiel, Germany \\ ${ }^{2}$ Dept. of Geology and Geophysics, Yale University, Box 208109, New Haven, Connecticut 06520-8109, USA \\ ${ }^{3}$ Alfred Wegener Institute for Polar and Marine Research, Box 120161, 27515 Bremerhaven, Germany \\ ${ }^{4}$ Division of Geophysics, Department of Physical Sciences, Box 64, 00014 University of Helsinki, Finland \\ ${ }^{5}$ Arctic Centre, University of Lapland, Box 122, 96101 Rovaniemi, Finland
}

\begin{abstract}
The abundance, size spectra and bacterial colonization of exopolymer particles were investigated in Antarctic sea ice and underlying water in the Bellingshausen Sea during April 2001. In addition to exopolymer particles (EP), different abiotic (temperature, salinity, ice texture, oxygen isotopic composition, inorganic nutrient concentrations) and biotic (particulate organic carbon/nitrogen, algal pigments, abundance and biomass of bacteria and diatoms) parameters were measured from the samples. The sea ice showed different communities occurring in physically distinct layers of the ice. Algal and bacterial biomass in the ice showed strong vertical gradients and ranged between 59.4 and $5140.4 \mathrm{\mu g} \mathrm{C}^{-1}$ and 8.8 and $119.4 \mu \mathrm{g} \mathrm{Cl}^{-1}$, respectively. EP concentrations in the sea ice were high, with EP abundance ranging between 10.2 and $260.1 \times 10^{6}$ particles $\mathrm{l}^{-1}$ and EP area between 3.4 and $92.1 \mathrm{~cm}^{2} \mathrm{l}^{-1}$. Median EP concentrations in the ice exceeded under-ice values by 1 order of magnitude. Crude estimates of integrated sea ice EP carbon were equivalent to $14-32 \%$ of the integrated POC, and to $34-78 \%$ of the integrated diatom biomass. The estimated integrated EP carbon in sea ice exceeded the bacterial biomass by a factor of 10 to 20. The abundance of EP was inversely correlated with size of the particles. EP size spectra showed relatively flat slopes, indicating a relatively large contribution of larger particles. The bacterial colonization of individual EP in the ice and in the underice water was not significantly different. In contrast, due to the large difference of EP concentrations in the 2 habitats, the median proportion of attached bacteria was much higher in the ice $(14.8 \%$ of the total bacterial number) than in the under-ice water $(1.9 \%$ of the total bacterial number). The data suggest that EP are an integral component of Antarctic sea ice communities and that EP serve as important substrates for ice-associated bacteria. After the ice melts in spring, large amounts of EP are available to be released to the water, where they may significantly contribute to and alter the particle flux of the ice-covered Southern Ocean.
\end{abstract}

KEY WORDS: Sea ice · Antarctica - Exopolymer particles · Extracellular polymeric substances · Particle colonization $\cdot$ Bacteria $\cdot$ Diatoms

Resale or republication not permitted without written consent of the publisher

\section{INTRODUCTION}

The annual formation, consolidation and subsequent melting of sea ice surrounding the Antarctic continent has a pivotal role in the biogeochemical cycles of the Southern Ocean (Lizotte \& Arrigo 1998, Thomas \& Dieckmann 2002). The interior of the sea ice serves as a habitat for ice-associated so-called sympagic communities inhabiting a brine-filled network of pores and channels (Horner et al. 1992, Gradinger 2002). The brine volume varies between approx. 1 and $30 \%$ of the ice volume, depending on ice-bulk salinity and temperature (Frankenstein \& Garner 1967, Weeks \& Ackley 1982). Sea ice communities consist of various 
organism groups like viruses, prokaryotes, protists and metazoa (Horner et al. 1992). Typically, sympagic communities are dominated by bacteria in terms of abundance, and diatoms in terms of biomass. Sea ice primary production contributes ca. $10-30 \%$ to the total primary production of the ice-covered Southern Ocean (Legendre et al. 1992, Arrigo et al. 1997).

Many aquatic organisms inhabiting pelagic, benthic and porous habitats produce copious amounts of extracellular polymeric substances (EPS) (Hoagland et al. 1993, Goto et al. 1999, Stoderegger \& Herndl 1999). Benthic diatoms have been reported to be important producers of EPS, which serve the algae in adhesion, locomotion, biogenic habitat stabilization and protection against harsh environmental conditions (Decho 1990, Hoagland et al. 1993, Cooksey \& Wigglesworth-Cooksey 1995, Smith \& Underwood 1998, 2000). In the pelagic realm, high EPS concentrations have been found during, or subsequent to, diatom blooms, when environmental conditions have deteriorated (Passow et al. 1994, Mopper et al. 1995, Myklestad 1995, Passow \& Alldredge 1995). EPS consist mainly of acid mucopolysaccharides and belong partly to the dissolved, colloidal and particulate size fractions (Alldredge \& Crocker 1995, Chin et al. 1998). In the plankton, exopolymer particles (EP, particles consisting of EPS) can be formed biotically as capsules and sheets, but are formed mainly abiotically by coagulation of dissolved organic matter and colloidal precursors (Zhou et al. 1998, Stoderegger \& Herndl 1999, Passow 2002a). EP are important in the agglutination of particles, provide the matrix of marine snow and, thus, have been considered as one of the most important biological factors controlling aggregation of phytoplankton blooms and their subsequent export from the upper layer of the ocean (Passow et al. 2001, Passow 2002b). Pelagic EP also serve as a substrate for bacteria (Passow \& Alldredge 1994, Mari \& Kiørboe 1996), and are known to harbor rich and diverse bacterial communities (Simon et al. 2002). Bacteria attached to EP may act in the formation as well as in the degradation of these particles (Smith et al. 1992, Ploug et al. 1999, Simon et al. 2002).

There is currently a substantial interest in the role of EPS in marine habitats, and recent studies have shown high concentrations of EPS in Arctic fast and pack ice (Krembs \& Engel 2001, Krembs et al. 2003, Meiners et al. 2003). Riebesell et al. (1991) showed that aggregate formation is a characteristic property of Antarctic sea ice algae, and other authors proposed that Antarctic sea ice may contain large amounts of EPS (Herborg et al. 2001). However, data on the Southern Ocean are still scarce (Hong et al. 1997), and to our knowledge no data exist for EP concentrations in Antarctic sea ice.

The scope of this study was therefore to describe the occurrence, abundance and size distribution of EP in Antarctic sea ice and the underlying water, to examine the bacterial colonization of sea ice EP, and to discuss the potential role of EP for the sea-ice habitat and its implications for the ice-covered Southern Ocean.

\section{MATERIALS AND METHODS}

Site and sampling. Free-drifting pack ice and underice water samples were collected during the expedition ANT XVIII-5b on RV 'Polarstern' in the marginal ice zone of the Bellingshausen Sea during late austral autumn 2001 (Fig. 1, for details see Bathmann 2002). The area showed ice coverage of $8 / 10$ to $9 / 10$; water depths at the stations ranged between 570 and $680 \mathrm{~m}$. Snow thickness was measured with a ruler at each sampling site prior to coring. At each station, 5 ice cores (A to E) were collected with a SIPRE-type ice corer (9 $\mathrm{cm}$ internal diameter) within an area of $1 \mathrm{~m}^{2}$. Two complete cores (A and B) were sealed in clean plastic tubing and kept frozen $\left(-30^{\circ} \mathrm{C}\right)$ for later analysis of ice texture and stable oxygen isotopic composition. Three cores (C, D and E) were cut immediately into 1 to $10 \mathrm{~cm}$ sections, transferred into acid-washed polyethylene boxes, and transported in insulated boxes to the ship's laboratory for further analysis of salinity, inorganic nutrients $\left(\mathrm{NO}_{3}{ }^{-}, \mathrm{PO}_{4}{ }^{3+}, \mathrm{Si}(\mathrm{OH})_{4}\right)$, particulate organic carbon (POC) and nitrogen (PON), algal pigments (chl $a$, pheopigments [pheo]) and for microscopical investigations. Under-ice water was sampled using a $10 \mathrm{~m}$ long polyethylene tube $(4 \mathrm{~cm}$ internal diameter) with a valve at one end. The unequipped end of the tube was lowered into the water with the valve open. At a depth of $10 \mathrm{~m}$, the valve was closed and the tube with the trapped water was retrieved. These 0 to $10 \mathrm{~m}$ integrated water samples were transferred to acidwashed containers and transported to the laboratory for further analysis.

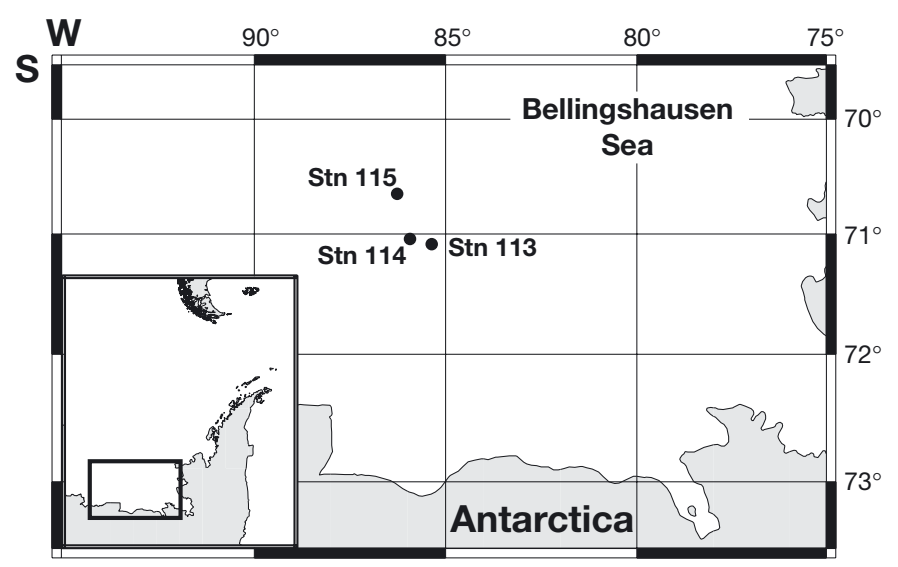

Fig. 1. Study area and location of stations in the Bellingshausen Sea. Station numbers represent day of the year, where January 1 = Day 1 
Ice structure and stable oxygen isotopic composition. The ice texture of Core A was determined by thin-section analysis (e.g. Kawamura et al. 2001). Based on ice crystal size and orientation, 3 stratigraphic units were distinguished: granular ice, columnar ice and intermediate granular/columnar ice (Eicken \& Lange 1989). Core B was cut into sections according to results of the structural analysis of Core A. Sections were melted and used for the determination of $\delta^{18} \mathrm{O}$ with a mass spectrometer (Finnigan MAT Delta $E_{\text {; }}$ precison: $\pm 0.1 \%$ ). Based on the combined textural and isotopic characteristics, ice cores were divided into 4 categories: snow ice, granular ice, columnar ice and intermediate granular/columnar ice.

Temperature, salinity, chemical parameters and pigments. Ice temperature was measured with a Testo720-thermometer immediately after coring from small holes drilled into Core $\mathrm{C}$ at 5 to $10 \mathrm{~cm}$ intervals. To prevent cooling of the ice core, these measurements were performed in a temperature-insulated plastic tube. For the analysis of salinity, inorganic nutrients, algal pigments (Core C) POC and PON (Core D) sections of ice cores were melted in the dark at $4^{\circ} \mathrm{C}$. Salinity of melted ice and water samples was measured with a WTW LF 191 conductometer. Subsamples $(50 \mathrm{ml})$ were fixed with $\mathrm{HgCl}_{2}$ (Kattner 1999) and stored frozen $\left(-30^{\circ} \mathrm{C}\right)$ until analysis for the concentration of $\mathrm{NO}_{3}{ }^{-}, \mathrm{PO}_{4}{ }^{3+}$ and $\mathrm{Si}(\mathrm{OH})_{4}$ using standard seawater procedures (Grasshoff et al. 1983). For the analysis of POC and PON, melted ice and water samples were filtered onto precombusted Whatman GF/F filters and combusted in a Carlo Erba NA 1500 CHN-Analyzer (Verardo et al. 1990). For the determination of chl $a$ and pheo concentrations, samples were filtered onto Whatman GF/F filters and analyzed fluorometrically with a Turner Designs 10-AU digital fluorometer, according to Arar \& Collins (1997).

Abundance and biomass of bacteria and diatoms. Core E was used for the microscopical investigation of bacteria, algae and EP and for the determination of the bacterial abundance of EP. Ice core sections (1 to $10 \mathrm{~cm}$ ) were melted in the dark at $4^{\circ} \mathrm{C}$ with an addition of $0.2 \mu \mathrm{m}$ filtered seawater to avoid osmotic stress (Garrison \& Buck 1986, Spindler \& Dieckmann 1986). Blanks of the filtered seawater were taken at each station and treated like the ice samples; the concentrations of blanks were insignificant for all parameters (bacteria, algae and EP). Immediately after the ice samples had melted, $250 \mathrm{ml}$ subsamples were fixed with $0.2 \mu \mathrm{m}$ filtered borax-buffered formalin ( $1 \%$ final concentration). Subsamples (30 to $100 \mathrm{ml}$ ) were filtered onto black $0.2 \mu \mathrm{m}$ (Filter A) and $0.8 \mu \mathrm{m}$ (Filter B) polycarbonate filters, stained with 4'6' diamidino-2phenylindole (DAPI), and mounted on microscope slides (Porter \& Feig 1980). For the calculation of the total bacterial number and bacterial biomass $(0.2 \mu \mathrm{m}$ filter), at least 400 cells were counted on a minimum of 20 fields. Estimates of bacterial biovolume were determined from length and width measurements of 100 cells per sample with a New Porton G12 grid (Graticules) at a final magnification of 1000×. Bacterial biovolume was converted into bacterial carbon using the formula $\mathrm{CC}=88.6 \times \mathrm{vol}^{0.59} \times 1.042$ (Simon \& Azam 1989), where CC (fg) and vol $\left(\mu^{3}\right)$ are the carbon content per cell and the cell volume, respectively. Filter $B(0.8 \mu \mathrm{m})$ was used for counting of centric and pennate diatoms. Calculation of diatom biomass was based on cell measurements and followed the recommendations of the Baltic Marine Environment Protection Commission-Helsinki Commission (1988).

Determination of EP. Determination of EP followed the method of Alldredge et al. (1993) for the determination of so-called transparent exopolymer particles (TEP). However, since TEP is a term primarily used for pelagic particles mainly formed by coagulation of dissolved precursors, the particles observed in the present study are more generally referred to as exopolymer particles (EP), because they were extracted from the porous sea ice matrix and may also contain fragments of disrupted biofilms. For the determination of EP, 2 to $30 \mathrm{ml}$ subsamples were filtered carefully onto $0.4 \mu \mathrm{m}$ polycarbonate filters (Filter C) supported with backing filters with a pressure difference of $<0.1$ bar. Samples were stained with $0.2 \mu \mathrm{m}$ pre-filtered Alcian Blue solution (Alldredge et al. 1993) and mounted on Cyto-Clear slides (Poretics) (Logan et al. 1994). Relative cover of total EP area on the filters was low $(<4.5 \%)$. EP abundance and size were measured semi-automatically at $400 \times$ magnification with a Leitz Aristoplan microscope connected to a Sony DXP-CCD video camera. A minimum of $500 \mathrm{EP}$ were videotaped and the videoframes were digitized. Contour lines of digitized EP images were traced manually and the area of individual particles was determined with a Leica QWIN $500 \mathrm{MC}$ image analysis system. Individual EP areas were converted to equivalent spherical diameters (ESD), which were assigned to 8 logarithmically increasing size classes ranging from 3 to $60 \mu \mathrm{m}$ ESD.

Particle size distributions are often described by power relations of the type $N=\mathrm{k}_{\mathrm{p}}{ }^{-\beta}$, or $\mathrm{d} N / \mathrm{d}\left(d_{\mathrm{p}}\right)=$ $\mathrm{k} d_{\mathrm{p}}{ }^{-(\beta+1)}$, where $\mathrm{d} N$ is the number of particles per unit volume in the size range $d_{\mathrm{p}}$ to $\left[d_{\mathrm{p}}+\mathrm{d}\left(d_{\mathrm{p}}\right)\right]$ (e.g. McCave 1984). The constant $\mathrm{k}$ depends on the concentration of the particles and $\beta$ describes the size distribution of the particles; the smaller $\beta$ is, the larger the fraction of large particles. A $\beta$ of 3 denotes equal particle volumes in the logarithmically increasing size classes (McCave 1984). We estimated $\beta+1$ values from the regressions of $\log \left[\mathrm{d} N / \mathrm{d}\left(d_{\mathrm{p}}\right)\right]$ versus $\log \left(d_{\mathrm{p}}\right)$. The magnitude of $\beta+1$ allows comparison of EP size frequencies at different stations and environments. 
Bacterial colonization of EP. To determine the number of bacteria attached to EP, 5 to $30 \mathrm{ml}$ subsamples of the fixed samples were filtered onto $0.4 \mu \mathrm{m}$ polycarbonate filters (Filter D) and double-stained with Alcian Blue and DAPI. After staining, filters were mounted on Cyto-Clear slides (Poretics) (Logan et al. 1994). For each sample, bacteria associated with 24 EP were enumerated by switching between brightfield and UV illumination. The individual EP were sized (see above), and associated bacteria were counted at a magnification of 1000x. Because EP are $3 \mathrm{D}$, the entire volume of each EP was examined by changing the microscopes focal plane during the observation. Hence, bacteria both on the surface and embedded in EP were counted (Mari \& Kiørboe 1996). A potential error (in this study: 6 to $18 \%$ ) in this enumeration is caused when free-living bacteria are retained by the filter beneath the examined EP. In order to estimate the fraction of total bacteria attached to EP, a relationship between EP size and the number of attached bacteria was calculated for each sample. The number of attached bacteria can be fitted to a power law function $\mathrm{n}=\mathrm{a} d_{\mathrm{p}}{ }^{\mathrm{b}}$, where $\mathrm{n}$ is the number of bacteria per EP, $d_{\mathrm{p}}$ is the ESD of the EP and $\mathrm{a}$ and $\mathrm{b}$ are constants for a given sample. Numbers of associated bacteria were plotted versus ESD in log-log coordinates to give estimates of $a$ and $b$. The fraction of attached bacteria was calculated by combining this relationship (results from Filter D), the size spectra of EP (results from Filter C) and the total bacterial numbers (results from Filter A) (Passow \& Alldredge 1994, Mari \& Kiørboe 1996).

Brine salinity was calculated as a function of ice temperature (Assur 1958); brine volume as a function of temperature and ice-bulk salinity (Frankenstein \& Garner 1967). Non-parametric Spearman-Rank correlations were used to determine relationships between biogenic parameters. To test for significant differences between median values, the Mann-Whitney $U$-test was applied (Sachs 1984). To test for significant differences between the bacterial colonization of EP in sea ice and water, analysis of covariance (ANCOVA) was performed.

\section{RESULTS}

\section{Temperature, salinity, chemical parameters and pigments}

Ice thickness at the sampling sites was very variable and ranged between 49 and $79 \mathrm{~cm}, 56$ and $68 \mathrm{~cm}$ and 47 and $65 \mathrm{~cm}$ at Stns 113, 114 and 115, respectively. All stations were snow covered, with snow thickness varying between 4 and $20 \mathrm{~cm}$. The sea ice texture was dominated by intermediate granular/columnar and granular ice, indicating dynamic, turbulent conditions during sea ice formation (Fig. 2). Snow ice layers, characterized by low $\delta^{18} \mathrm{O}$ values (Fig. 2a), were found at all stations and contributed between 4 and $19 \%$ to total ice thickness (Fig. 2b). Stns 113 and 114 showed internal porous layers, with upper boundaries located approx. 10 to $15 \mathrm{~cm}$ below the freeboard level of the ice floes (freeboard levels were: Stn 113, $2.5 \mathrm{~cm}$; $\mathrm{Stn} 114,1.5 \mathrm{~cm}$ ). Ice temperatures ranged from -8.8 to $-2.4^{\circ} \mathrm{C}$, and showed typical linear late-autumn profiles, with lowest temperatures in the uppermost parts of the ice (Fig. 2c). Brine salinities, calculated as a function of ice temperature, were high, with values between 42.5 and 132.8 (median: 79.9, data not shown). Vertical profiles of sea ice bulk salinity are presented in Fig. 3. Bulk salinities ranged between 6.4 and 14.2 (median: 9.5). Bulk salinity and temperature measurements were used to calculate brine vol-
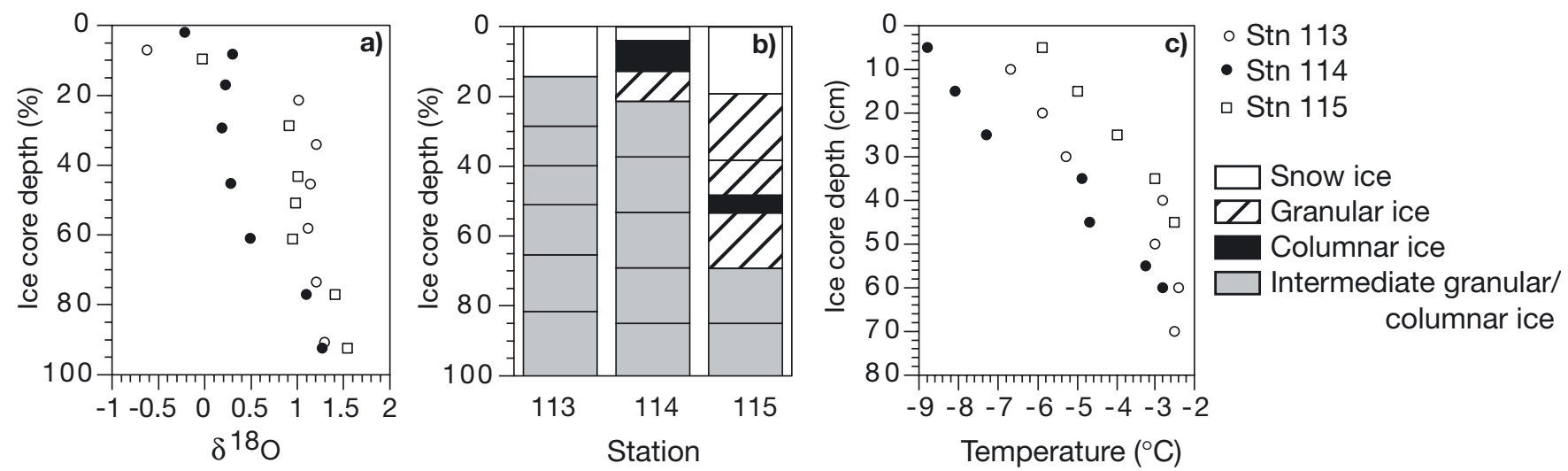

Fig. 2. (a) Vertical distribution of $\delta^{18} \mathrm{O}$ values $\left(\mathrm{ml}^{-1}\right.$; given against Standard Mean Ocean Water), (b) vertical distribution of textural ice classes (for definitions see 'Materials and methods'), and (c) vertical profiles of sea ice temperature 
umes, i.e. the fluid phase of the sea ice system in which dissolved matter is enriched and which serves as the actual habitat for the sea ice biota. Brine volumes ranged between 6.7 and $24.6 \%$ (median: $11.9 \%$, data not shown).

Vertical profiles of nutrient concentrations in the ice and under-ice water values are shown in Fig. 3. With the exception of $\mathrm{NO}_{3}^{-}$concentrations, which were positively correlated with ice depth (Spearman-Rank correlation: $\rho=0.545, p=0.0046$ ), nutrient concentrations in the sea ice were neither correlated to ice depth nor to ice bulk salinity. $\mathrm{NO}_{3}{ }^{-}$concentrations in the ice were highly variable and ranged between 0.67 and $9.35 \mu \mathrm{M}$. $\mathrm{PO}_{4}{ }^{3+}$ concentrations in the ice varied from 0.34 to $9.2 \mu \mathrm{M}$. $\mathrm{Si}(\mathrm{OH})_{4}$ concentrations in the ice of Stns 113 and 114 showed extremely high peaks in the ice interior, coinciding with peak concentrations of algal pigments and biomass (Figs. 3 \& 4). Except for $\mathrm{NO}_{3}{ }^{-}$, sea ice at Stns 113 and 114 showed much higher nutrient concentrations than at Stn 115. Nutrient concentrations in the water were rather similar at all stations, with the exception of the high $\mathrm{NO}_{3}{ }^{-}$concentration at Stn 113.

Chl a concentrations in the ice peaked in surface, interior and bottom layers (Fig. 3), values ranged between 0.2 and $228.2 \mu \mathrm{g} \mathrm{l}^{-1}$ (median: 65.6 $\mathrm{\mu g} \mathrm{l}^{-1}$ ). Highest chl a concentrations occurred in the internal porous layer at Stn 113. Chl a concentrations in the water were much lower, with a median concentration of only $0.2 \mu \mathrm{g} \mathrm{l}^{-1}$. The chl a:pheo ratio in the ice showed maxima in top and interior layers, the ratio was very high in the water samples at Stns 114 and 115 (Fig. 3). POC and PON concentrations in the ice varied between 190.8 and $9988.5 \mathrm{\mu g}^{-1}$ (median POC:

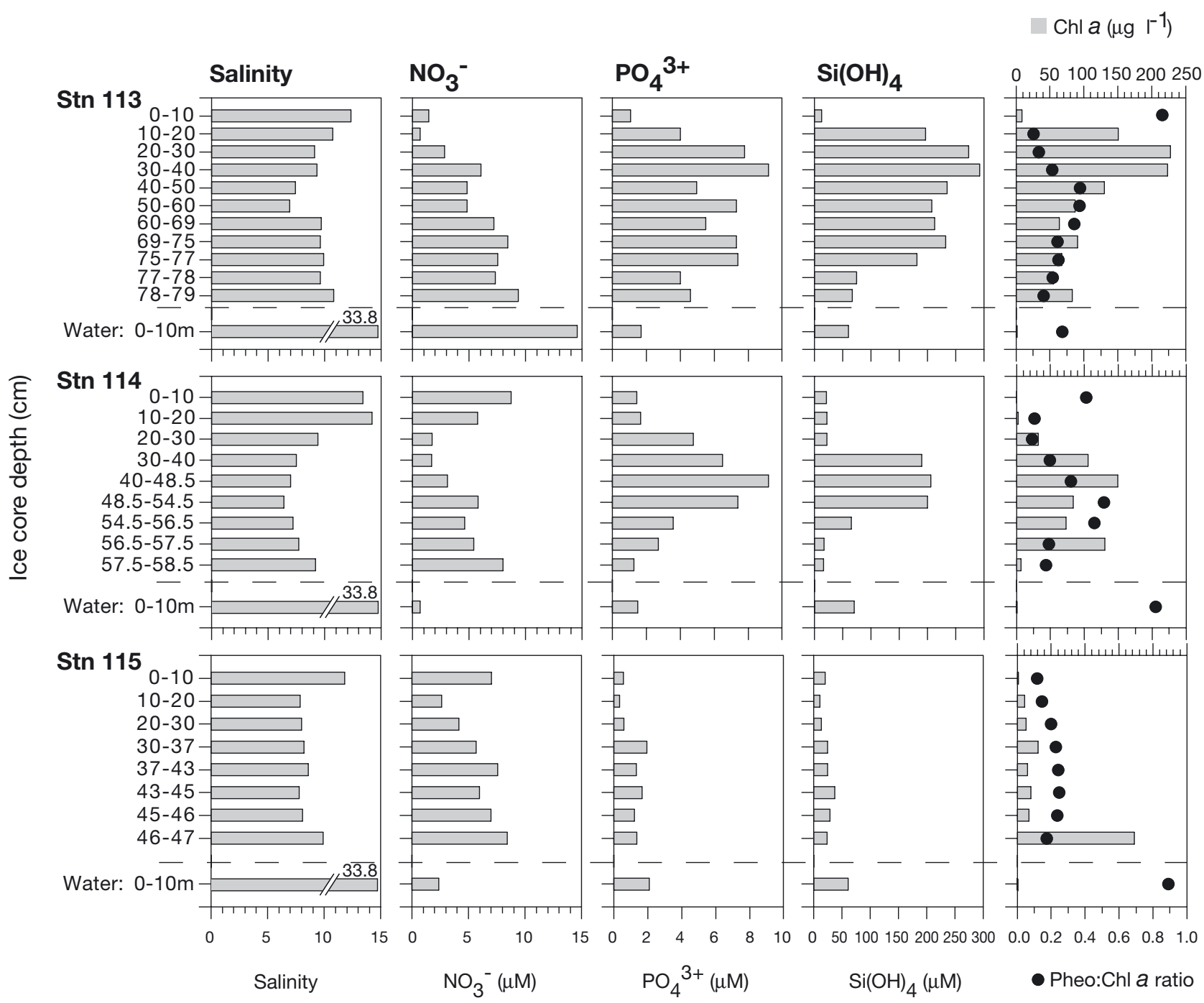

Fig. 3. Vertical distribution patterns of ice bulk salinity, $\mathrm{NO}_{3}{ }^{-}, \mathrm{PO}_{4}{ }^{3+}, \mathrm{Si}(\mathrm{OH})_{4}$, chl $a$ and the pheophytin:chl $a$ ratio in sea ice, and values for the underlying water 


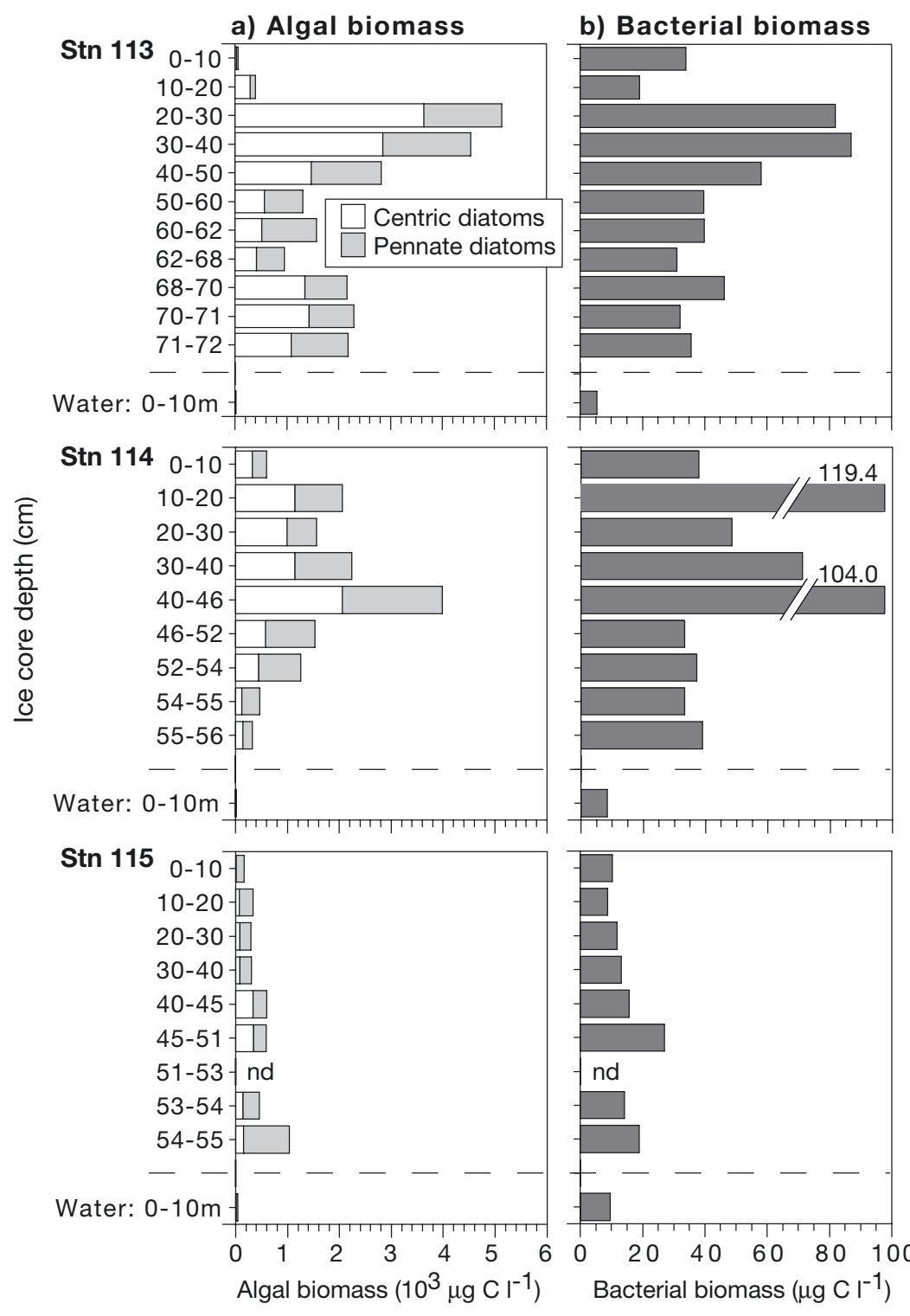

Fig. 4. Vertical distribution of algal (centric and pennate diatoms) and bacterial biomass in sea ice and underlying water. nd = no data
$2594.5 \mu \mathrm{g} \mathrm{l^{-1 }}$ ) and 17.4 to $1568.7 \mu \mathrm{g} \mathrm{l^{-1 }}$ (median PON: $364.8 \mu \mathrm{g} \mathrm{l}^{-1}$ ), respectively (data not shown). Water concentrations were much lower, with POC ranging from 39.7 to $355.9 \mu \mathrm{g} \mathrm{l}^{-1}$ and PON from 5.4 to $45.9 \mu \mathrm{g} \mathrm{l}^{-1}$ (median POC: $106.9 \mu \mathrm{g} \mathrm{\textrm {l } ^ { - 1 }}$, median PON: $13.7 \mu \mathrm{g} \mathrm{l}^{-1}$ ). C:N ratios in the sea ice showed values between 6.8 and 12.8 (median: 7.6); water values were similar at all stations with a median value of 9.0. Integrated ice values of POC and PON ranged between 437.3 and $3207.4 \mathrm{mg} \mathrm{m}^{-2}$ (median: $2034.3 \mathrm{mg} \mathrm{m}^{-2}$ ) and 63.1 and $504.6 \mathrm{mg} \mathrm{m}^{-2}$ (median: $316.36 \mathrm{mg} \mathrm{m}^{-2}$ ), respectively.

\section{Algal and bacterial abundance and biomass}

The results of the microscopical counts and biomass estimates for algae and bacteria are summarized in Table 1. Algal biomass peaked in the surface, interior and bottom of the ice floes (Fig. 4). Pennate diatoms are often the most important primary producers in Antarctic sea ice. However, in this study the interior algal assemblages and the integrated abundance and biomass at Stns 113 and 114 were dominated by centric diatoms. Dominant centric species were Chaetoceros sp., Corethron sp., Thalassiosira sp. and Rhizosolenia sp. At Stn 115, in contrast, pennate forms dominated the diatom assemblage. Iceassociated pennate diatoms were predominated by Fragilariopsis sp., Nitzschia sp. and Navicula sp. Algal abundance and biomass was extremely low in the under-ice water (Table 1). No Phaeocystis sp. were observed in the samples.

Table 1. Abundance and biomass of bacteria, pennate diatoms and centric diatoms in sea ice and underlying water. Values given as median (range). Integration depth for ice values = ice thickness, integration depth for water values $=10 \mathrm{~m}$

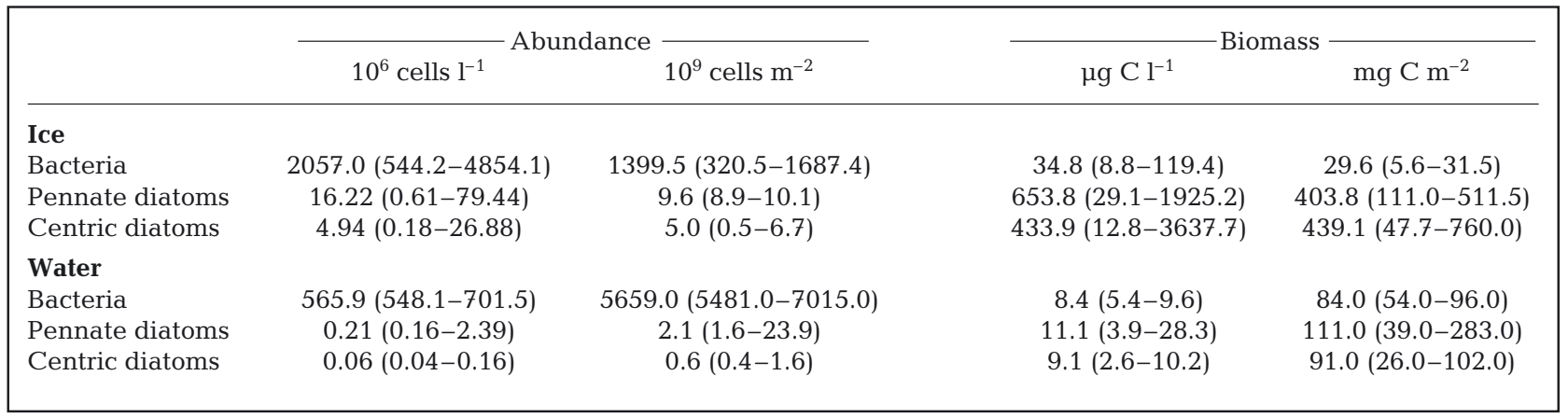




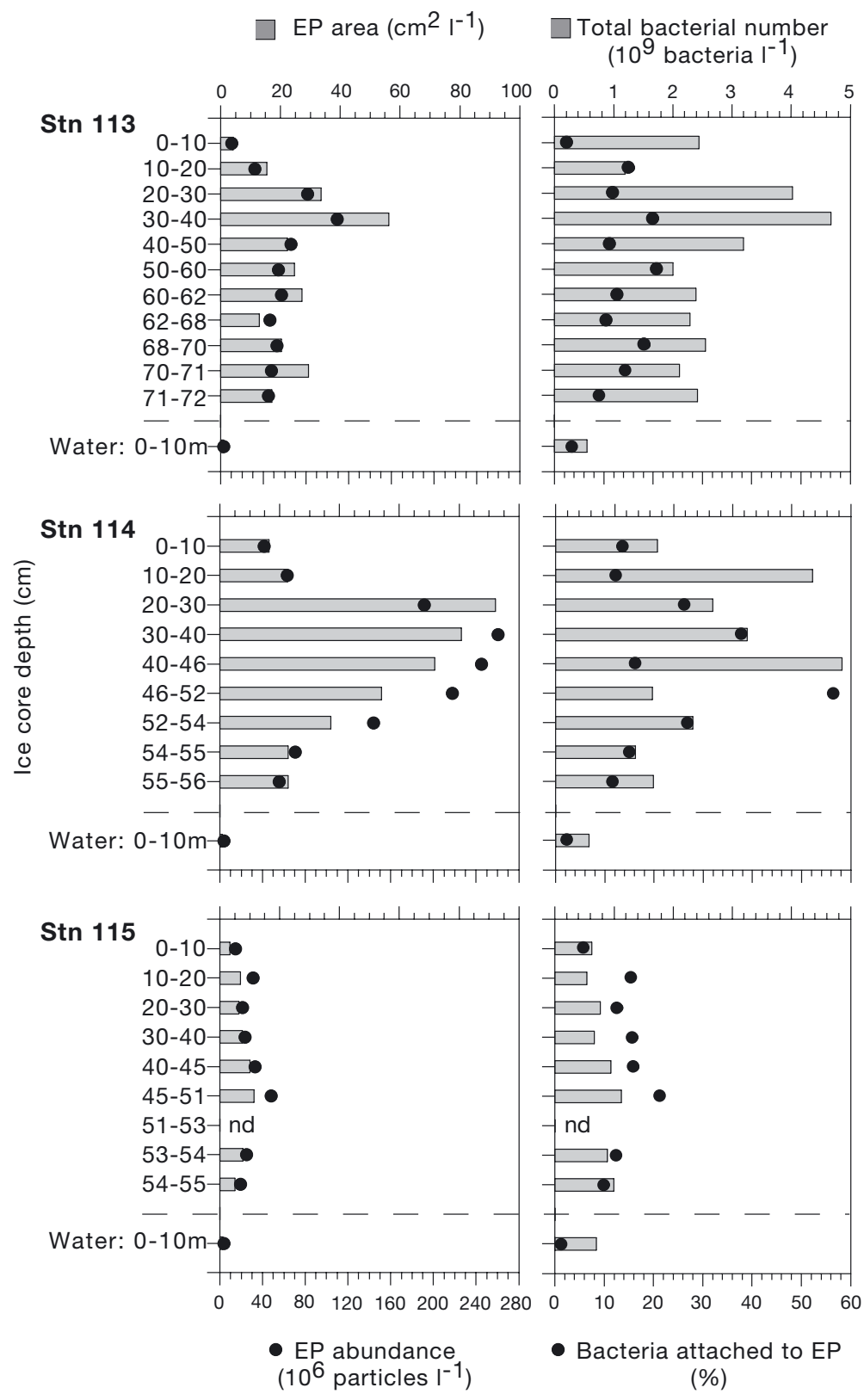

Fig. 5. Vertical distribution of exopolymer particle (EP) area, EP abundance, total bacterial number and the relative number of bacteria attached to EP (\%) in sea ice and underlyingwater. $\mathrm{nd}=$ no data

High bacterial abundances and biomasses were observed throughout the entire ice thickness (Figs. 4 \& 5), with maximum values of bacterial biomass coinciding well with peak values of ice algal biomass. A close relationship was detected for the ice data of bacterial and pennate diatom biomass $(\rho=0.708, p=0.0002)$ and bacterial and centric diatom biomass $(\rho=0.796, p<$ 0.0001). Bacterial concentration and biomass in the under-ice water were considerably lower (Table 1).

\section{EP abundance, area and size distribution}

EP were found in all ice and water samples. The concentration of EP is reported in 2 ways: EP abundance (particles $\mathrm{l}^{-1}$ ) and EP area $\left(\mathrm{cm}^{2} \mathrm{l}^{-1}\right)$. At all stations, the highest concentrations of both EP abundance and area peaked in the interior of the ice (Fig. 5). EP abundance and area in the ice varied between 10.2 and $260.1 \times 10^{6}$ particles $\mathrm{l}^{-1}$ and 3.4 and $92.1 \mathrm{~cm}^{2} \mathrm{l}^{-1}$, respectively. EP abundance in the water varied between 3.0 and $3.6 \times 10^{6}$ particles $\mathrm{l}^{-1}$, the EP area between 0.8 and $1.1 \mathrm{~cm}^{2} \mathrm{l}^{-1}$. The median concentrations in the ice (EP abundance: $50.2 \times$ $10^{6}$ particles $\mathrm{l}^{-1}$, EP area: $21.3 \mathrm{~cm}^{2} \mathrm{l}^{-1}$ ) exceeded medians in the water (EP abundance: $3.6 \times 10^{6}$ particles $\mathrm{l}^{-1}$, EP area: $1.0 \mathrm{~cm}^{2} \mathrm{l}^{-1}$ ) by 1 order of magnitude. This difference was statistically significant for both parameters (Mann-Whitney $U$ test: $\mathrm{p}=0.005$ for both EP abundance and area).

Although EP concentrations showed wide variability, the general size distributions of EP were relatively similar. EP abundance decreased with EP size (ESD), and this relationship could be described by powerlaw functions. Values for their slopes in log-log regressions $(\beta+1)$ in the sea ice samples ranged between 1.5 and 2.5, and were not correlated with ice depth. $\beta+1$ values of the water samples varied between 2.0 and 2.5. The relative EP size frequencies of the pooled ice and water samples are given in Fig. 6 . The slopes $(\beta+1$ values) were relatively flat in both habitats and indicate a relativly large amount of larger EP particles.

In the sea ice, a close coupling of algal and bacterial biomass and EP was indicated by highly significant Spearman-Rank correlations. Bacterial biomass was significantly correlated to both EP abundance $(\rho=0.692, p<0.0003)$ and EP area $(\rho=0.703, p=0.0003)$. High Spearman-Rank coefficients were also found for correlations of EP abundance and EP area with pennate diatom biomass (EP abundance: $\rho=$ 0.699, $p=0.0003$, EP area: $\rho=0.687, p=0.0004$ ) and centric diatom biomass (EP abundance: $\rho=$ 0.729, $p=0.0002$, EP area: $\rho=0.756, p<0.0001$ ).

\section{Bacterial colonization of EP}

Doublestaining EP with Alcian Blue and DAPI showed that all investigated particles were colonized by bacteria. Bacteria were observed both on the surface of and inside the EP. The colonization was very variable, with a range of 1 to 220 bacteria $\mathrm{EP}^{-1}$ 


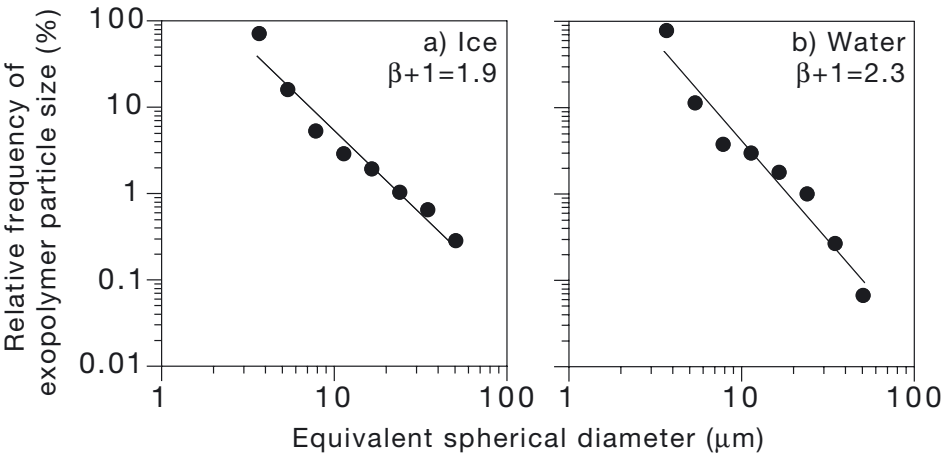

Fig. 6. Relative size frequencies of exopolymer particles (EP) for the (a) pooled sea ice and (b) underlying water data

(median: 15 bacteria $\mathrm{EP}^{-1}$ ) in the sea ice and 1 to 103 bacteria $\mathrm{EP}^{-1}$ (median: 13 bacteria $\mathrm{EP}^{-1}$ ) in the water samples. Colonization of EP in the sea ice and in the underlying water showed no significant difference (Fig. 7; ANCOVA: $F=2.789, \mathrm{p}=0.0953$ ). The absolute number of bacteria in both sea ice and water increased with EP size (Fig. 7), whereas the specific numbers of attached bacteria (e.g. number of bacteria per unit area) decreased with the size of EP (data not shown). A total range of 1.5 to $56.5 \%$ of the total bacterial number was attached to EP. The median of the relative number of attached bacteria in sea ice $(14.8 \%)$ was significantly higher than the median value $(1.9 \%)$ of the water samples (Mann-Whitney $U$-test: $\mathrm{p}=0.0062$ ). The percentage of bacteria associated with EP in the sea ice was significantly correlated with EP abundance $(\rho=0.542, p=0.0048)$ and EP area $(\rho=0.538, p=0.0051)$.

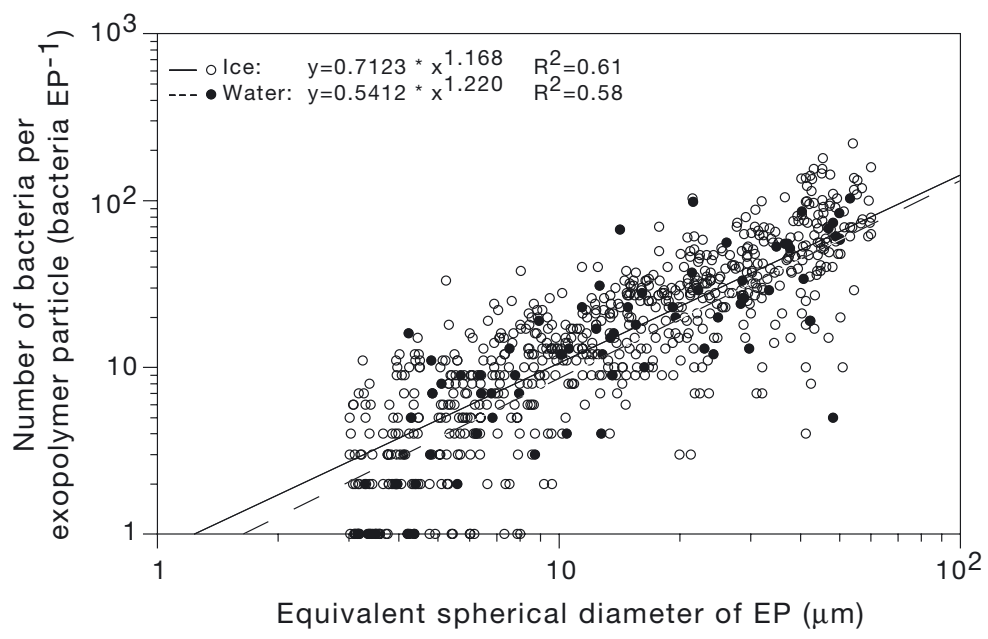

Fig. 7. Total number of bacteria per individual exopolymer particle (EP) versus size of the respective EP in sea ice (O) and water $(\bullet)$

\section{DISCUSSION}

\section{Discussion of methods}

This study gives the first data on the abundance, size distribution and bacterial colonization of EP in Antarctic sea ice and the underlying water. High concentrations and characteristic size distributions of EP were found in all samples. The determination of EP in sea ice, however, is subject to methodological difficulties (Krembs \& Engel 2001). Melting of ice causes salinity changes, which may affect the stainability of EP with the cationic dye Alcian Blue. Melting of samples also destroys the internal ice structure, which allows for free interaction of particles, which were previously restricted to the delicate brine channels inside the ice. In the present study, sea ice was melted by addition of sterile-filtered sea water to reduce osmotic stress during melting (Garrison \& Buck 1986, Spindler \& Dieckmann 1986). Since sea ice generally contains higher DOC concentrations than water (Thomas et al. 1995, 1998, Herborg et al. 2001), the procedure additionally diluted the samples and, thus, reduced encounter and coagulation rates of dissolved organic molecules, colloidal material, and small EP particles, which have all been reported as potential EP precursors (Chin et al. 1998, Passow 2000, 2002a,b). The method used therefore minimized biological EP production by bacteria and algae (as potential response to osmotic stress) as well as abiotic EP production from different precursors. However, influences of ice melting on the EP concentrations and characteristics cannot be totally ruled out.

\section{EP concentration, distribution and characteristics}

EP abundances in sea ice were generally very high and comparable to or exceeding maximum concentrations reported from different marine pelagic habitats (Alldredge et al. 1993, Passow \& Alldredge 1994, Mari \& Kiørboe 1996, Mari \& Burd 1998, Simon et al. 2002). Krembs \& Engel (2001) highlighted the role of EP in Arctic pack ice of the Laptev Sea and reported on EP areas between below detection and at $16 \mathrm{~cm}^{2} \mathrm{l}^{-1}$, with a median of $2.9 \mathrm{~cm}^{2} \mathrm{l}^{-1}$. Meiners et al. (2003), using the same method as in the present study, found similar values (range: 0.6 to $16.2 \mathrm{~cm}^{2} \mathrm{l}^{-1}$, median: $5.8 \mathrm{~cm}^{2} \mathrm{l}^{-1}$ ) in Greenland Sea pack ice. The median value of the present study $\left(21.3 \mathrm{~cm}^{2}\right.$ $\mathrm{l}^{-1}$ ) is considerably higher, demonstrating that Antarctic sea ice harbors extremely large amounts of EP. 
At all stations, maximum EP concentrations occurred in layers coinciding with the maxima of bacterial and algal biomass. At Stns 113 and 114, the EP and biomass maxima were located in a layer of porous ice (of intermediate granular/columnar or granular texture) approximately $10 \mathrm{~cm}$ below the freeboard of the ice floes. Fritsen \& Sullivan (1997) proposed a conceptual model for the distribution and development of microbial communities in Antarctic pack ice, and described the occurrence of these biomass-rich surface and surface/ internal communities for Antarctic second-year sea ice (sea ice that survived the summer melt season), whereas first-year sea ice normally shows lower biomass, often located in the interior and at the bottom of the ice floes. Therefore, despite similar ice bulk salinities at all stations, the distinct biomass distributions (Fig. 4) suggest that Stns 113 and 114 resemble older ice floes, which allowed for the accumulation of biomass and EP (Fig. 5) to the high levels observed. Salinities $>7.8$, as well as low biomass and low EP concentrations, indicate that the sea ice at Stn 115 was relatively young, but nevertheless already contained EP concentrations which exceeded water values by a factor of 4 to 13 . The data therefore suggest that EP are an integral component of sympagic communities of Antarctic first-year and second-year pack ice, and that high EP concentrations occur especially in biomass-rich layers of second-year sea ice.

The number of EP was negatively correlated with EP size in both sea ice and under-ice water. The $\beta+1$ values of the size distributions were small, and indicated a relatively large proportion of larger particles. $\beta+1$ values in this study differed from the theoretical value of $\beta+1=4$, consistent with steady-state size spectra of EP being formed by shear coagulation from smaller particles (McCave 1984). The size spectra of EP were comparable to those reported for Arctic sea ice of different age (Krembs \& Engel 2001, Meiners et al. 2003). A high proportion of relatively large particles has been explained by EP formation in the form of mucus sheets, coagulation of smaller EP with non-EP particles, and the fractal nature of EP (Passow \& Alldredge 1994, Mari \& Kiørboe 1996). The high concentrations of sympagic diatoms, potentially producing mucus in the form of sheets, may serve as an explanation for the size distribution observed in the present study. However, the elevated amount of larger EP particles can also be attributed to other characteristics in the sea ice and under-ice habitat, e.g. grazing or dissaggregation of larger EP or disruption of sympagic biofilms, an occurrence that has been proposed by Thomas \& Dieckmann (2002).

\section{Sources and formation of EP}

The high EP concentrations in the ice can be caused by different mechanisms: physical enrich- ment of EP during ice formation, abiotic production of EP from dissolved and/or colloidal precursors, and biological production of EP by sympagic organisms.

\section{Physical enrichment}

Different processes have been described for the physical incorporation and enrichment of sediment and organisms into newly forming and existing ice sheets (Ackley 1982, Reimnitz et al. 1990, Grossmann \& Dieckmann 1994, Spindler 1994). Exeptionally high accumulations have been observed in granular ice, associated with dynamic, turbulent ice growth conditions and high growth rates (Weeks \& Ackley 1982, Clarke \& Ackley 1984). Granular ice predominates in Antarctic pack ice, with a contribution of 40 to $70 \%$ (Clarke \& Ackley 1984, Scott et al. 1994). Granular ice was also an important fraction in the sea ice under investigation. It is therefore assumed that EP are already enriched in young Antarctic sea ice formed under dynamic conditions. This hypothesis is supported by the enriched EP values observed in the relatively young sea ice at Stn 115.

\section{Abiotic formation}

High concentrations of dissolved organic carbon (DOC) have been reported from sea ice of both polar oceans and have been attributed to mechanical damage of organisms during the formation and consolidation of the ice, to grazing activity of sympagic proto- and metazoans, to osmotic adjustment of ice organisms and to increased algal extracellular release (Gleitz \& Thomas 1993, Thomas et al. 1995, 1998, 2001). Herborg et al. (2001) reported high concentrations of carbohydrates, contributing up to $31 \%$ of the DOC pool in Antarctic pack ice. DOC, and especially carbohydrates, are important precursors of polymers and thus for EP formation (Myklestad 1995, Passow 2000). Sea ice temperature in combination with ice bulk salinity determines the brine volume and directly controls the salinity of the brine (Assur 1958, Frankenstein \& Garner 1967). During winter, decreasing temperatures in sea ice therefore increase brine salinities, and concentrate DOC in decreasing brine volumes. Aggregation is a positive function of both the concentration of divalent cations (Simon et al. 2002) and precursor concentration (Chin et al. 1998). Increasing salinity and DOC concentration during cooling of the sea ice may therefore serve in concert for the abiotic formation of $\mathrm{EP}$ in the brine channel system. 


\section{Biotic production}

A third possible explanation for the high EP concentrations in sea ice is the direct production of polymeric substances from cell internal carbon pools. Diatoms, especially, produce copious amounts of EPS which serve the algae in adhesion, locomotion and the buffering of environmental stress (Hoagland et al. 1993, Cooksey \& Wigglesworth-Cooksey 1995, Wetherbee et al. 1998). Recently, protective microhabitats around diatoms in Arctic sea ice have been observed with in situ microscopical techniques (Junge et al. 2001, Krembs et al. 2003). Increased EPS production by algae has also been described for senescent diatom blooms and as a response to high salinities, low temperatures, low irradiances and nutrient limitation (Aletsee \& Jahnke 1992, Hoagland et al. 1993, Passow \& Alldredge 1994, Mopper et al. 1995, Liu \& Buskey 2000). These conditions are typical for Antarctic sea ice communities during the autumn season, when irradiance levels and temperatures decrease drastically. For example, in this study ice temperatures in the internal communities with highest EP concentrations were very low, ranging between -5.9 and $-7.7^{\circ} \mathrm{C}$. Calculated brine salinities in these layers ranged between ca. 100 and 120, and caused harsh osmotic stress to the inhabiting organisms. During the cooling of the sea ice, brine channels become increasingly disconnected (Golden et al. 1998, Eicken et al. 2000, Krembs et al. 2000), which reduces nutrient-availability on small scales and therefore increases nutrient stress in microhabitats, a process that can enhance EPS production. In this study, bulk nutrient concentrations in sea ice were generally high. Maximum $\mathrm{Si}(\mathrm{OH})_{4}$ concentrations measured in this study were 5 to 6 times higher than maximum values reported in other studies on Antarctic pack ice (Dieckmann et al. 1991, Garrison \& Buck 1991, Gleitz et al. 1995) and are possibly the result of dissolution of diatom frustules in our nutrient samples, which were not filtered before fixation with $\mathrm{HgCl}_{2}$. Therefore, despite careful fixation, storage and analysis of the samples, the extremely high $\mathrm{Si}(\mathrm{OH})_{4}$ data could be erroneous. Despite this shortcoming, we calculated nutrient concentrations in the brine from bulk nutrient concentrations and the theoretically derived brine volumes. These theoretical values ranged between 7.7 and $105.1 \mu \mathrm{M} \mathrm{NO}_{3}{ }^{-}, 4.2$ and $122.7 \mu \mathrm{M}$ $\mathrm{PO}_{4}{ }^{3+}$ and 77.2 and $3289.2 \mu \mathrm{M} \mathrm{Si}(\mathrm{OH})_{4}$, and were much higher than half-saturation constants ( $K_{s}$ values) reported for mixed natural phytoplankton assemblages (Sommer 1998). This suggests that the sea ice algae were not nutrient limited during the time of investigation, and that this factor was not responsible for the high EP values observed. However, nutrient limitation during Antarctic ice algal blooms has been reported (e.g. Gleitz et al. 1995, Kristiansen et al. 1998) and may have enhanced the production of EP in the interior of the ice floes at Stns 113 and 114 during spring and summer. The high EP concentrations at these stations may therefore represent a signal of a previous situation of nutrient limitation once algal-derived refractory EP had accumulated in the ice.

\section{Producers of EP}

Algae, and especially pennate diatoms, are considered to be the most important producers of EPS in marine benthic and planktonic habitats (Hoagland et al. 1993, Smith \& Underwood 1998, 2000, Passow 2002a). However, bacteria are also capable of producing EP, but their role in EP production has only recently been examined and is not fully understood (Passow 2002a, Simon et al. 2002). In this study, EP abundance and area showed significant correlations to both algal biomass and bacterial biomass. In order to estimate the importance of algal and bacterial derived EP in the sea ice, published EPS production rates of algae and bacteria were used for the calculation of daily production rates of the EPS of these groups in the sea ice. Due to the lack of data of cold-adapted organisms, cell-specific production rates of temperate epipelic diatoms (6.31 to $31.46 \mathrm{pg}$ glucan equivalents cell ${ }^{-1} \mathrm{~d}^{-1}$; Smith \& Underwood 2000) and temperate planktonic bacteria (4 amol C cell ${ }^{-1} \mathrm{~d}^{-1}$, Stoderegger \& Herndl 1999) were used. Neglecting temperature effects, and assuming a carbon:glucan ratio of 0.4 , estimated EPS production of diatoms was, on average, 195.1 $\mu \mathrm{g} \mathrm{C} \mathrm{l}^{-1} \mathrm{~d}^{-1}$ (range: 6.1 to $581.2 \mu \mathrm{g} \mathrm{C} \mathrm{l}^{-1} \mathrm{~d}^{-1}$ ); the estimated bacterial EPS production averaged only $2.5 \mu \mathrm{g} \mathrm{C}^{-1} \mathrm{~d}^{-1}$ (range: 0.6 to $5.6 \mu \mathrm{g} \mathrm{C} \mathrm{l}^{-1} \mathrm{~d}^{-1}$ ). The diatom EPS production:bacterial EPS production ratio averaged 102.5 (range: 2.2 to 507.5). Hence, the estimated algal EPS production exceeded the bacterial EPS production by, on average, 2 orders of magnitude, indicating that diatoms were the most important EPS producers in the sea ice habitat. These estimates are consistent with results from pelagic studies from lower latitudes, which report that diatoms are the main producers of EP (Passow et al. 1994, Passow \& Alldredge 1995).

\section{EP carbon}

Crude estimates of EP carbon were calculated using the formula given by Mari (1999) for laboratory-made (transparent) EP with TEP-C $\left(\mu \mathrm{g} \mathrm{C} \mathrm{TEP}{ }^{-1}\right)=0.25 \times$ $10^{-6} \mathrm{r}^{2.55}$, where $\mathrm{r}$ is the equivalent spherical radius and 2.55 is the fractal dimension of the (transparent) EP. 
The estimated integrated sea ice EP carbon was equivalent to $14-32 \%$ of the integrated POC values, $34-78 \%$ of the integrated algal biomass (sum of pennate and centric diatoms) and $1157-2090 \%$ of the integrated bacterial biomass. Keeping in mind the problems in transferring characteristics (volume, carbon-content) of laboratory-made TEP to sea ice EP, the data nevertheless indicate that EP significantly contribute to the carbon pool in Antarctic sea ice. The estimates are similar to values from planktonic studies, showing that aggregates contribute between 4 and $30 \%$ to pelagic POC (Alldredge \& Silver 1988, Riebesell 1991, Simon et al. 2002) and to EP carbon estimates in Arctic sea ice, with an average contribution of $24 \%$ to integrated POC (Meiners et al. 2003).

\section{EP colonization}

Different studies on Antarctic sea ice have reported the high number of epiphytic bacteria in the sea ice habitat (Ackley \& Sullivan 1994, Archer et al. 1996, Thomas et al. 1998), but no data on the colonization of EP by sympagic bacteria have been published. In the pelagic realm, EP and larger aggregates can serve bacteria as special microhabitats, and have been recognized as sites of increased microbial activity (Smith et al. 1992, Ploug et al. 1999, Sherr et al. 1999, Ayo et al. 2001, Grossart et al. 2003). Junge et al. (2002) report that a remarkably high fraction of the total number of respiring sea ice bacteria is associated with particles. In the present study, the total number of bacteria attached to individual EP ranged between 1 and 220 bacteria $\mathrm{EP}^{-1}$ and was within the range reported in pelagic studies (Passow \& Alldredge 1994, Mari \& Kiørboe 1996, Simon et al. 2002). The high variability in the colonization of similar sized EP indicates differences in the degree of colonization, and was possibly caused by the different age and chemical composition of the EP (Passow \& Alldredge 1994). The total number of attached bacteria increased with EP size, whereas the specific number (e.g. number of bacteria per unit area) decreased with size. This relationship has also been reported for planktonic aggregates and has been attributed to the fact that porosity of aggregates increases with size (Mari \& Kiørboe 1996, Ploug et al. 1999, Simon et al. 2002).

The percentage of attached bacteria shows a wide range in different planktonic habitats (e.g. Alldredge \& Gottschalk 1990, Turley \& Stutt 2000), and depends mainly on the abundance of aggregates (Simon et al. 2002). In most pelagic environments, the percentage of attached bacteria constitutes less than $10 \%$, and often less than $5 \%$, of the total bacterial number (Alldredge \& Gotschalk 1990, Turley \& Stutt 2000, Simon et al.
2002). The median percentage of bacteria attached to EP $(1.9 \%)$ in the water samples of this study falls very well in this range. The median percentage $(14.8 \%)$ in the ice samples was relatively high, indicating favorable conditions for bacteria associated with EP in the sea ice habitat.

Sea ice EP may serve not only as a carbon source for sympagic bacteria, but may also account for the high bacterial diversity in the sea ice systems (Bowman et al. 1997a,b, Brown \& Bowman 2001) by providing microhabitats for distinct bacterial groups. Planktonic microaggregates have been proposed to provide special microenvironments in their interior, which can show elevated nutrient concentrations and depleted oxygen concentrations compared to the surrounding water (Ploug \& Jørgensen 1999, Alldredge 2000). Assuming incorporation of EP into sea ice during iceformation, EP may also serve in the transport of distinct bacterial groups, such as anoxygenic and surfaceassociated forms from the water column into the sea ice during its formation. Junge et al. (2002) report on an isolate from Arctic sea ice related to a strain isolated from marine snow aggregates, thus supporting this hypothesis.

\section{CONCLUSION}

In conclusion, the high concentrations of EP in sea ice are most likely the result of different processes, including (1) physical enrichment of EP, (2) biological production of EP by algae and also bacteria, and (3) spontaneous accretion of DOC, whereby (2) and (3) are possibly enhanced due to the extreme physico-chemical conditions within the brine channel system of the sea ice during the summer-winter transition. The observed EP were densely colonized by bacteria, and sea ice EP may serve as important sites for the turnover of particulate organic matter, as well as microhabitats providing distinct environmental conditions for sympagic bacteria. The crude estimates of EP carbon indicate that EP constitutes a hitherto largely neglected carbon fraction of Antarctic sea ice. The data suggest that during austral summer, when 60 to $80 \%$ of the Antarctic sea ice cover is melting (Zwally et al. 1983), large amounts of EP are available to be released to the water column, where they may contribute and influence the particle flux in the icecovered Southern Ocean.

Acknowledgements. We would like to thank the captain, crew and scientific party of RV 'Polarstern' cruise ANT XVIII$5 \mathrm{~b}$ for their support of our ice work. We especially would like to thank our collegues A. Belem, A. Scheltz and K. Tuschling for their help in the field. Thanks to T. Martma for providing the $\delta^{18} \mathrm{O}$ data. The helpful comments of M. Spindler, B. Bluhm, R. Gradinger and 2 anonymous reviewers are grate- 
fully acknowledged. This work was supported by the Deutsche Forschungsgemeinschaft (grant SP-377-1-3) and by the Deutscher Akademischer Austauschdienst (grant 313-SFPPP-pz).

\section{LITERATURE CITED}

Ackley SF (1982) Ice scavenging and nucleation: two mechanisms for incorporation of algae into newly-forming sea ice. EOS 63:54-55

Ackley SF, Sullivan CW (1994) Physical controls on the development and characteristics of Antarctic sea ice biological communities-a review and synthesis. Deep-Sea Res I 41: 1583-1604

Aletsee L, Jahnke J (1992) Growth and productivity of the psychrophilic marine diatoms Thalassiosira antarctica Comber and Nitzschia frigida Grunow in batch cultures at temperatures below the freezing point of sea water. Polar Biol 11:643-647

Alldredge AL (2000) Interstitial dissolved organic carbon (DOC) concentrations within sinking marine aggregates and their potential contribution to carbon flux. Limnol Oceanogr 45:1245-1253

Alldredge AL, Crocker KM (1995) Why do sinking mucilage aggregates accumulate in the water column? Sci Total Environ 165:15-22

Alldredge AL, Gotschalk C (1990) The relative contribution of marine snow of different origin to biological processes in coastal waters. Cont Shelf Res 10:41-58

Alldredge AL, Silver ML (1988) Characteristics, dynamics and significance of marine snow. Prog Oceanogr 20:41-82

Alldredge A, Passow U, Logan B (1993) The abundance and significance of a class of large transparent organic particles in the ocean. Deep-Sea Res I 40:1131-1140

Arar EJ, Collins GB (1997) Method 445.0: in vitro determination of chlorophyll $a$ and pheophytin $a$ in marine and freshwater algae by fluorescence, Publication No. 455. US Environmental Protection Agency, Cincinnati, OH, p 1-17

Archer SD, Leakey RJG, Burkill PH, Sleigh MA, Appleby CJ (1996) Microbial ecology of sea ice at coastal Antarctic site: community composition, biomass and temporal change. Mar Ecol Prog Ser 135:179-195

Arrigo KR, Worthen DL, Lizotte MP, Dixon P, Dieckmann G (1997) Primary production in Antarctic sea ice. Science 276:394-397

Assur A (1958) Composition of sea ice and its tensile strength. Publ Natl Res Counc Can 598:106-138

Ayo B, Unanue M, Azúa I, Gorsky G, Turley C, Iriberri J (2001) Kinetics of glucose and amino acid uptake by attached and free-living marine bacteria in oligotrophic waters. Mar Biol 138:1071-1076

Baltic Marine Environment Protection Commision-Helsinki Commission (1988) Guidelines for the Baltic Monitoring Programme for the third stage; Part D. Biological determinands. Baltic Sea Environment Proceedings 27D. The Finnish Government Printing Centre, Helsinki, p 1-161

Bathmann U (2002) The expedition ANTARKTIS XVIII/5b of the Research Vessel 'Polarstern' in 2001. Ber Polarforsch 407:1-98

Bowman JP, Brown MV, Nichols DS (1997a) Biodiversity and ecophysiology of bacteria associated with Antarctic sea ice. Antarct Sci 9:134-142

Bowman JP, McCammon SA, Brown MV, Nichols DS, McMeekin TA (1997b) Diversity and association of psychrophilic bacteria in Antarctic sea ice. Appl Environ Microbiol 63:3068-3078
Brown MV, Bowman JP (2001) A molecular phylogenetic survey of sea-ice microbial communities. FEMS Microbiol Ecol 35:267-275

Chin WC, Orellana MV, Verdugo P (1998) Spontaneous assembly of marine dissolved organic matter into polymer gels. Nature 391:568-572

Clarke DB, Ackley SF (1984) Sea ice structure and biological activity in the Antarctic marginal ice zone. J Geophys Res C 89:2087-2095

Cooksey KE, Wigglesworth-Cooksey B (1995) Adhesion of bacteria and diatoms to surfaces in the sea: a review. Aquat Microb Ecol 9:87-96

Decho AW (1990) Microbial exopolymer secretions in ocean environments: their role(s) in food webs and marine processes. Oceanogr Mar Biol Annu Rev 28:73-153

Dieckmann GS, Lange MA, Ackley SF, Jennings JC Jr (1991) The nutrient status in sea ice of the Weddell Sea during winter: effects of sea ice texture and algae. Polar Biol 11: 449-456

Eicken H, Lange MA (1989) Development and properties of sea ice in the coastal regime of the southeastern Weddell Sea. J Geophys Res C 94:8193-8206

Eicken H, Bock C, Wittig R, Miller H, Poertner HO (2000) Nuclear magnetic resonance imaging of sea ice pore fluids: methods and thermal evolution of pore microstructure. Cold Regions Sci Technol 31:207-225

Frankenstein G, Garner R (1967) Equations for determining the brine volume of sea ice from $-0.5^{\circ}$ to $-22.9^{\circ} \mathrm{C}$. J Glaciol 6:943-944

Fritsen CH, Sullivan CW (1997) Distributions and dynamics of microbial communities in the pack ice of the western Weddell Sea, Antarctica. In: Battaglia B, Valencia J, Walton DWH (eds) Antarctic communities: species, structure and survival. Cambridge University Press, Cambridge, p 101-106

Garrison DL, Buck KR (1986) Organism losses during ice melting: a serious bias in sea ice community studies. Polar Biol 6:237-239

Garrison DL, Buck KR (1991) Surface-layer sea ice assemblages in Antarctic pack ice during the austral spring: environmental conditions, primary production and community structure. Mar Ecol Prog Ser 75:161-172

Gleitz M, Thomas DN (1993) Variation in phytoplankton standing stock, chemical composition and physiology during sea-ice formation in the southeastern Weddell Sea. J Exp Mar Biol Ecol 173:211-230

Gleitz M, Rutgers van der Loeff M, Thomas DN, Dieckmann GS, Millero FJ (1995) Comparison of summer and winter inorganic carbon, oxygen and nutrient concentrations in Antarctic sea ice brine. Mar Chem 51:81-91

Golden KM, Ackley SF, Lytle VI (1998) The percolation phase transition in sea ice. Science 282:2238-2241

Goto N, Kawamura T, Mitamura O, Terrai H (1999) Importance of extracellular organic carbon production in the total primary production by tidal flat diatoms in comparison to phytoplankton. Mar Ecol Prog Ser 190:289-295

Gradinger R (2002) Sea ice microorganisms. In: Bitton G (ed) The encyclopedia of environmental microbiology. Wiley, New York, p 2833-2844

Grasshoff K, Ehrhardt M, Kremling K (1983) Methods of seawater analyses. Verlag Chemie, Weinheim

Grossart HP, Hietanen S, Ploug H (2003) Microbial dynamics on diatom aggregates in Øresund, Denmark. Mar Ecol Prog Ser 249:69-78

Grossmann S, Dieckmann GS (1994) Bacterial standing stock, activity, and carbon production during formation and growth of sea ice in the Weddell Sea, Antarctica. Appl 
Environ Microbiol 60:2746-2753

Herborg LM, Thomas DN, Kennedy H, Haas C, Dieckmann GS (2001) Dissolved carbohydrates in Antarctic sea ice. Antarct Science 13:119-125

Hoagland KD, Rosowski JR, Gretz MR, Roemer SC (1993) Diatom extracellular polymeric substances. Function, fine structure, chemistry, and physiology. J Phycol 29:537-566

Hong Y, Smith WO Jr, White AM (1997) Studies on transparent exopolymer particles (TEP) produced in the Ross Sea (Antarctica) and by Phaeocystis antarctica (Prymnesiophyceae). J Phycol 33:368-376

Horner R, Ackley SF, Dieckmann GS, Gulliksen B and 6 others (1992) Ecology of sea ice biota 1. Habitat, terminology, and methodology. Polar Biol 12:417-427

Junge K, Krembs C, Deming J, Stierle A, Eicken H (2001) A microscopic approach to investigate bacteria under in-situ conditions in sea-ice samples. Ann Glaciol 33:304-310

Junge K, Imhoff F, Staley T, Deming JW (2002) Phylogenetic diversity of numerically important Arctic sea-ice bacteria at subzero temperature. Microb Ecol 43:315-328

Kattner G (1999) Storage of dissolved inorganic nutrients in seawater: poisoning with mercuric chloride. Mar Chem 67:61-66

Kawamura T, Shirasawa K, Ishikawa N, Lindfors A and 5 others (2001) Time-series observations of the structure and properties of brackish ice in the Gulf of Finland. Ann Glaciol 33:1-4

Krembs C, Engel A (2001) Abundance and variability of microorganisms and transparent exopolymer particles across the ice-water interface of melting first-year sea ice in the Laptev Sea (Arctic). Mar Biol 138:173-185

Krembs C, Gradinger R, Spindler M (2000) Implications of brine channel geometry and surface area for the interaction of sympagic organisms in Arctic sea ice. J Exp Mar Biol Ecol 243:55-80

Krembs C, Eicken H, Junge K, Deming JW (2003) High concentrations of exopolymeric substances in Arctic winter ice: implications for the polar ocean carbon cycle and cryoprotection of diatoms. Deep-Sea Res I 49:2163-2181

Kristiansen S, Farbrot T, Kuosa H, Myklestad S, von Quillfeldt $\mathrm{CH}$ (1998) Nitrogen uptake in the infiltration community, an ice algal community in Antarctic pack-ice. Polar Biol 19:307-315

Legendre L, Ackley SF, Dieckmann GS, Gulliksen B and 6 others (1992) Ecology of sea ice biota 2. Global significance. Polar Biol 12:429-444

Liu H, Buskey EJ (2000) Hypersalinity enhances the production of extracellular polymeric substance (EPS) in the Texas brown tide alga, Aureoumbra lagunensis (Pelagophyceae). J Phycol 36:71-77

Lizotte MP, Arrigo KR (1998) Antarctic sea ice: biological processes, interactions and variability (Antarctic Research Series 73). American Geophysical Union, Washington, DC

Logan BE, Grossart HP, Simon M (1994) Direct observation of phytoplankton, TEP and aggregates on polycarbonate filters using brightfield microscopy. J Plankton Res 16: $1811-1815$

Mari X (1999) Carbon content and C:N ratio of transparent exopolymeric particles (TEP) produced by bubbling exudates of diatoms. Mar Ecol Prog Ser 183:59-71

Mari X, Burd A (1998) Seasonal size spectra of transparent exopolymeric particles (TEP) in a coastal sea and comparison with those predicted using coagulation theory. Mar Ecol Prog Ser 163:63-76

Mari X, Kiørboe T (1996) Abundance, size distribution and bacterial colonization of transparent exopolymeric particles (TEP) during spring in the Kattegat. J Plankton Res
18:969-986

McCave IN (1984) Size spectra and aggregation of suspended particles in the deep ocean. Deep-Sea Res 31:329-352

Meiners K, Gradinger R, Fehling J, Civitarese G, Spindler M (2003) Vertical distribution of exopolymer particles in sea ice of the Fram Strait (Arctic) during autumn. Mar Ecol Prog Ser 248:1-13

Mopper K, Zhou J, Ramana KS, Passow U, Dam HG, Drapeau DT (1995) The role of surface-active carbohydrates in the flocculation of a diatom bloom in a mesocosm. Deep-Sea Res II 42:47-73

Myklestad SM (1995) Release of extracellular products by phytoplankton with special emphasis on polysaccharides. Sci Total Environ 165:155-164

Passow U (2000) Formation of transparent exopolymer particles, TEP, from dissolved precursor material. Mar Ecol Prog Ser 192:1-11

Passow U (2002a) Production of transparent exopolymer particles (TEP) by phyto- and bacterioplankton. Mar Ecol Prog Ser 236:1-12

Passow U (2002b) Transparent exopolymer particles (TEP) in aquatic environments. Prog Oceanogr 55:287-333

Passow U, Alldredge AL (1994) Distribution, size and bacterial colonization of transparent exopolymer particles (TEP) in the ocean. Mar Ecol Prog Ser 113:185-198

Passow U, Alldredge AL (1995) Mass aggregation of a diatom bloom in a mesocosm: the role of TEP. Deep-Sea Res II 42: 99-109

Passow U, Alldredge AL, Logan BE (1994) The role of particulate carbohydrate exudates in the flocculation of diatom blooms. Deep-Sea Res I 41:335-337

Passow U, Shipe RF, Murray A, Pak DK, Brzezinski MA, Alldredge AL (2001) The origin of transparent exopolymer particles (TEP) and their role in sedimentation of particulate matter. Cont Shelf Res 21:327-346

Ploug H, Jørgensen BB (1999) A net-jet flow system for mass transfer and microelectrode studies in sinking aggregates. Mar Ecol Prog Ser 176:270-290

Ploug H, Grossart HP, Azam F, Jørgensen BB (1999) Photosynthesis, respiration, and carbon turnover in sinking marine snow from surface waters of Southern California Bight: implications for the carbon cycle in the ocean. Mar Ecol Prog Ser 179:1-11

Porter KG, Feig YS (1980) The use of DAPI for identifying and counting aquatic microflora. Limnol Oceanogr 25:943-948

Reimnitz E, Kempema EW, Weber WS, Clayton JR, Payne JR (1990) Suspended-matter scavenging by rising frazil ice as observed in tank experiments. In: Ackley SF, Weeks WF (eds) Sea ice properties and processes. Proc WF Weeks Sea Ice Symp. US Army Corps of Engineers, Hanover, p $97-100$

Riebesell U (1991) Particle aggregation during a diatom bloom. II. Biological aspects. Mar Ecol Prog Ser 69: 281-291

Riebesell U, Schloss I, Smetacek V (1991) Aggregation of algae released from melting sea ice: implications for seeding and sedimentation. Polar Biol 11:239-248

Sachs L (1984) Angewandte statistik. Springer-Verlag, Berlin

Scott P, McMinn A, Hosie G (1994) Physical parameters influencing diatom community structure in eastern Antarctic sea ice. Polar Biol 14:507-517

Sherr BF, del Giorgio P, Sherr EB (1999) Estimating abundance and single-cell characteristics of respiring bacteria via the redox dye CTC. Aquat Microb Ecol 18:117-131

Simon M, Azam F (1989) Protein content and protein synthesis rates of planktonic marine bacteria. Mar Ecol Prog Ser 51:201-213 
Simon M, Grossart HP, Schweitzer B, Ploug H (2002) Microbial ecology of organic aggregates in aquatic ecosystems. Aquat Microb Ecol 28:175-211

Smith DC, Simon M, Alldredge AL, Azam F (1992) Intense hydrolytic activity on marine aggregates and implications for rapid particle dissolution. Nature 359:139-142

Smith DJ, Underwood GJC (1998) Exopolymer production by intertidal epipelic diatoms. Limnol Oceanogr 43: 1578-1591

Smith DJ, Underwood GJC (2000) The production of extracellular carbohydrates by estuarine benthic diatoms: the effects of growth phase and light and dark treatment. J Phycol 36:321-333

Sommer U (1998) Biologische Meereskunde. SpringerVerlag, Berlin

Spindler M (1994) Notes on the biology of sea ice in the Arctic and Antarctic. Polar Biol 14:319-324

Spindler M, Dieckmann GS (1986) Distribution and abundance of the planktic foraminifer Neoglobquadrina pachyderma in sea ice of the Weddell Sea (Antarctica). Polar Biol 5:185-191

Stoderegger KE, Herndl GJ (1999) Production of exopolymer particles by marine bacterioplankton under contrasting turbulent conditions. Mar Ecol Prog Ser 189:9-16

Thomas DN, Dieckmann GS (2002) Antarctic sea ice-a habitat for extremophiles. Science 295:641-644

Thomas DN, Lara RJ, Eicken H, Kattner G, Skoog A (1995) Dissolved organic matter in Arctic multi-year sea ice during winter: major components and relationship to ice characteristics. Polar Biol 15:477-483

Thomas DN, Lara RJ, Haas C, Schnack-Schiel SB, Dieckmann

Editorial responsibility: Gerhard Herndl,

Den Burg, The Netherlands
GS, Kattner G, Nöthig EM, Mizdalski E (1998) Biological soup within decaying summer sea ice in the Amundsen Sea, Antarctica. In: Lizotte MP, Arrigo KR (eds) Antarctic sea ice: biological processes, interactions and variability (Antarctic Research Series 73). American Geophysical Union, Washington, DC, p 161-171

Thomas DN, Kattner G, Engbrodt R, Giannelli V, Kennedy H, Haas C, Dieckmann, GS (2001) Dissolved organic matter in Antarctic sea ice. Ann Glaciol 33:297-303

Turley CM, Stutt ED (2000) Depth-related cell-specific bacterial leucine incorporation rates on particles and its biogeochemical significance in the Northwest Mediterranean. Limnol Oceanogr 45:419-425

Verardo DJ, Froelich PN, McIntyre A (1990) Determination of organic carbon and nitrogen in marine sediments using the Carlo Erba Na-1500 analyzer. Deep-Sea Res I 37:157-167

Weeks WF, Ackley SF (1982) The growth, structure, and properties of sea ice. Cold Regions Res Engin Lab Monogr 82-1:1-130

Wetherbee R, Lind JL, Burke J, Quatrano RS (1998) The first kiss: establishment and control of initial adhesion by raphid diatoms. J Phycol 34:9-15

Zhou J, Mopper K, Passow U (1998) The role of surface-active carbohydrates in the formation of transparent exopolymer particles by bubble adsorption of seawater. Limnol Oceanogr 43:1860-1871

Zwally HJ, Comiso JC, Parkinson CL, Campbell WJ, Carsey FD, Gloersen P (1983) Antarctic sea ice, 1973-1976: satellite passive-microwave observations. NASA Publication SP-459, NASA Scientific and Technical Information Program, Washington, DC

Submitted: September 7, 2003; Accepted: January 3, 2004 Proofs received from author(s): May 3, 2004 